\title{
Mountain Riverine Floods in Ecuador: Issues, Challenges, and Opportunities
}

\author{
Juan Pinos ${ }^{1 *}$ and Luis Timbe ${ }^{2}$ \\ ${ }^{1}$ Facultad de Ciencia y Tecnología, Universidad del Azuay, Cuenca, Ecuador, ${ }^{2}$ Departamento de Recursos Hídricos y \\ Ciencias Ambientales, Universidad de Cuenca, Cuenca, Ecuador
}

Increasing urbanization and development along rivers, together with climate change, exacerbate future flood risk in Ecuador. Current policy strategies in the highlands greatly need improvement. Politicians must rethink if the governmental environmental institutions and inhabitants of the highlands are prepared to respond to future small- and large-scale flood episodes. The purpose of this paper is to identify the issues facing flood risk management (FRM) in the Ecuadorian highlands with a view to finding approaches for overcoming them. We focus on three specific concerns: an assessment of the deficiencies of current flood risk management, the development of diverse strategies to combat flooding, and the need for an overarching vision for future actions

OPEN ACCESS

Edited by:

Saket Pande,

Delft University of

Technology, Netherlands

Reviewed by:

Carol Harden,

The University of Tennessee, Knoxville,

United States

Julie A. Winkler,

Michigan State University,

United States

*Correspondence:

Juan Pinos

jpinos@uazuay.edu.ec

Specialty section:

This article was submitted to

Water and Human Systems,

a section of the journal

Frontiers in Water

Received: 26 March 2020 Accepted: 08 September 2020

Published: 28 October 2020

Citation:

Pinos J and Timbe L (2020) Mountain

Riverine Floods in Ecuador: Issues,

Challenges, and Opportunities.

Front. Water 2:545880.

doi: 10.3389/frwa.2020.545880 and research. These are presented within a theoretical framework together with the authors' recommendations of adaptation options for Ecuador's newly emerging flood challenges. Traditional and novel flood risk management approaches are required, including smart land-use planning, implementation of structural and non-structural measures, coordinated water governance systems with public participation, and the development and improvement of resilience to flooding. Moreover, academic input is a fundamental component of FRM to fill current knowledge gaps regarding mountain floods. This article addresses further research developments that are required to articulate and enable targeted FRM. To our knowledge, no previous publication has specifically dealt with FRM issues in the Ecuadorian highlands, thus, an overview of the current status of FRM is necessary. It is hoped that the challenges associated with flood management discussed here can be addressed over time.

Keywords: flood risk management, flood hazard, flood mitigation, risk communication, mountain rivers, Ecuadorian highlands, human settlement

\section{INTRODUCTION}

Losses arising from flood impacts in Ecuadorian cities and rural areas in the coastal, highlands, and Amazon regions include fatalities, damage to infrastructure and agriculture, interruptions to business and education, along with negative impacts on long-term human health and welfare. In fact, economic losses were estimated at 238 million USD for the extreme flooding events in 2012 (SENPLADES, 2012). Flooding events frequently occur in the low-lands along the coast (Galarza-Villamar et al., 2018), which are more densely populated than the highlands and Amazon regions. Consequently, greater attention has been paid to policies related to coastal flooding compared to floods in other regions, leading to the preferential implementation 
of flood countermeasures along the coast. However, the potential damage of floods in Ecuadorian highlands must not be underestimated because of increased exposure of people and assets due to the increasing rates of population growth and urbanization in the flood-prone areas of the highlands. The Ecuadorian mountain system (i.e., the inter-Andean valley) consists of a long narrow plateau running north and south that is delimited by two mountain chains with the presence of numerous volcanoes (Figure 1). Here, steep slopes with relatively abrupt changes to valley floors are part of the landscape, with towns often nestled in valley floors near rivers and at stream confluences.

Mountain riverine floods typically occur in steep, small catchments after heavy rainfall episodes. As a result, high-velocity flood discharge into tributaries can transport high loads of suspended sediment and debris to the main rivers (Figure 2A). Mountain rivers that are prone to flooding frequently pass through valleys where settlements and infrastructure exist (Figure 2B). Flood risk management, which can be defined as a systematic process that integrates the full spectrum of management policies and processes from technical analysis to institutional arrangements, is necessary to reduce losses from mountain riverine floods. However, the current efforts in Ecuador are insufficient, addressing only a small portion of the complex FRM framework and leaving several aspects unexplored (e.g., flood loss models and robust decision support systems). Furthermore, in comparison with many developed countries, Ecuador has no general guidelines for FRM.

As an example, the National Flood Insurance Program (NFIP) administrated by Federal Emergency Management Agency (FEMA) that standardizes FRM across the USA incorporates flood zoning along rivers courses as a key component for effective FRM (local governments manage development in floodways based on a 1/100-years flood analysis to identify flood-hazard areas and develop flood-risk maps) (Bubeck et al., 2017). In our case, the municipalities are responsible for land-use planning, which include floodplain management, and for this task, each municipality has its own policies ${ }^{1}$. Most regulations about restrictions on the floodplain next to the river do not consider the topography and flood magnitude, and only a fixed distance from the riverbank is used.

There is no comprehensive legislation about inundation modeling and flood mapping so that these types of analysis are not common. For example, SENAGUA has performed a few studies on flood modeling and mapping at local scale in the Southern Andes of Ecuador for protection measures and land-use planning (SENAGUA, 2011, 2014). However, local governments often do not use these results (e.g., flood maps) to improve floodplain management due to the lack of coordination and communication.

Clearly, more effective FRM in Ecuador is required; hence, efforts to improve FRM in Ecuadorian highlands have broad relevance due to its heterogeneity in topography, steep riverbed slopes, highly variable precipitation patterns (both spatial and temporal), and a poor hydrometeorological network. These

${ }^{1}$ Articles No. 45 and 430 of the Organic Code of Territorial Organization, Autonomy and Decentralization (COOTAD). characteristics have restricted, for example, hydraulic modeling and flood mapping when compared with the coast. Up to now, no previous publication has assessed FRM in Ecuador; thus, an overview of its current strengths and limitations is necessary.

The aim of this article is to provide a review of the current state of FRM in the Andean mountain range of Ecuador. Also, a perspective of the issues regarding FRM along with the authors' viewpoints on the challenges and limitations of flood management strategies in the Ecuadorian highlands is presented. Finally, an agenda for future research on FRM in the Andean mountain range of Ecuador is suggested in order to fill the current knowledge gaps.

\section{FLOOD RISK MANAGEMENT ISSUES}

The National Service of Risk Management and Emergency (SNGRE) is the main agency responsible for FRM in Ecuador together with the National Water Secretariat (SENAGUA). However, other institutions are indirectly involved such as the National Institute of Meteorology and Hydrology (INAMHI), the Planning and Development Secretariat (SENPLADES), and local municipalities via their autonomous environmental/risk units. There is a considerable overlap of policies, objectives, functions, and responsibilities among these agencies. Moreover, while it is estimated that $45.2 \%$ of the natural disasters in Ecuador reported between 1996 and 2016 were floods (Galarza-Villamar et al., 2018), SNGRE has a very large number of responsibilities (floods, volcanic eruptions, earthquakes, landslides, and other natural hazards) and cannot focus its efforts on a specific hazard, reducing its response capacity.

The key issues in the current FRM are as follows. First, there are long sequential chains of interactions among institutions; for example, INAMHI provides hydrometeorological information so that later, SENAGUA can combine the hydrometric and hydrological information to develop flood studies. Finally, with this information, SNGRE together with SENPLADES and municipalities could formulate the risk management plan. However, the lack of timely coordination and communication makes it difficult to achieve the expected goals.

Second, the nine hydrographic demarcations of SENAGUA do not correspond with the planning zones of the other organizations involved in FRM, leading to issues with administrative responsibility. SNGRE and SENPLADES are divided into nine planning zones across the country, whereas INAMHI is centralized. The main objective in setting up the demarcations and planning zones was for the administrative organization of government entities and agencies to improve the coordination of actions with local governments (e.g., municipalities). Still, there is an overlap of activities and responsibilities. For example, INAMHI is supposed to be in charge of the hydro-meteorological monitoring in the country, nevertheless, other local governments (e.g., municipalities), regional agencies (e.g., SENAGUA) and private companies (e.g., hydropower firms) have also their own monitoring networks. This issue results in a waste of human and economic resources. 


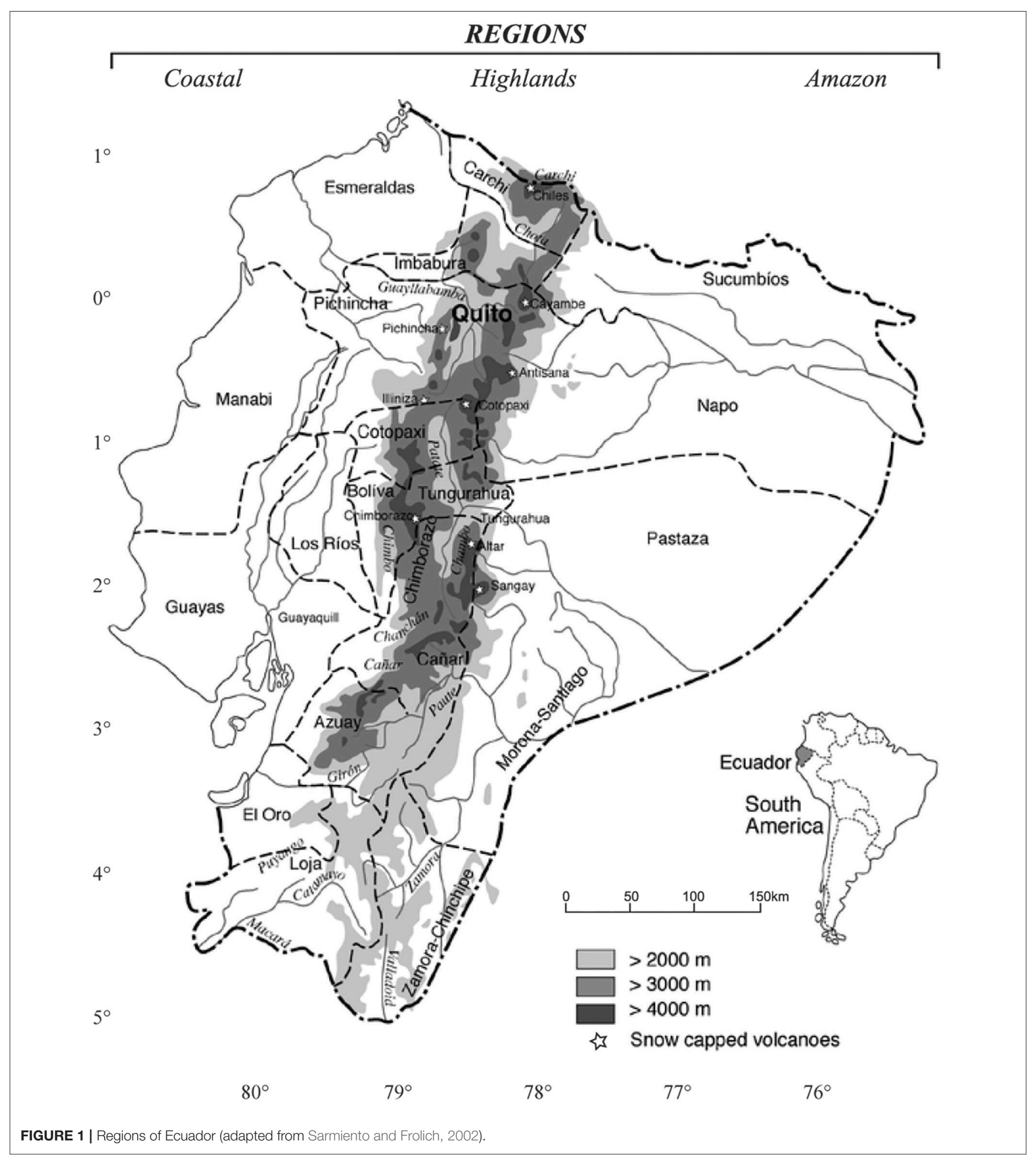

Third, there currently is a lack of staff, including, among others, hydrologists, risk managers, and climate modelers. In addition, the hiring of inadequately trained water professionals and their involvement in decision-making could lead to serious consequences in economic, environmental, and human life terms. As stated by Knight (2013), public organizations need to ensure that the internal technical knowledge (e.g., hydraulics) and skills are up to date, for example, to effectively engage with external consultants when needed (e.g., for modeling or design tasks). 

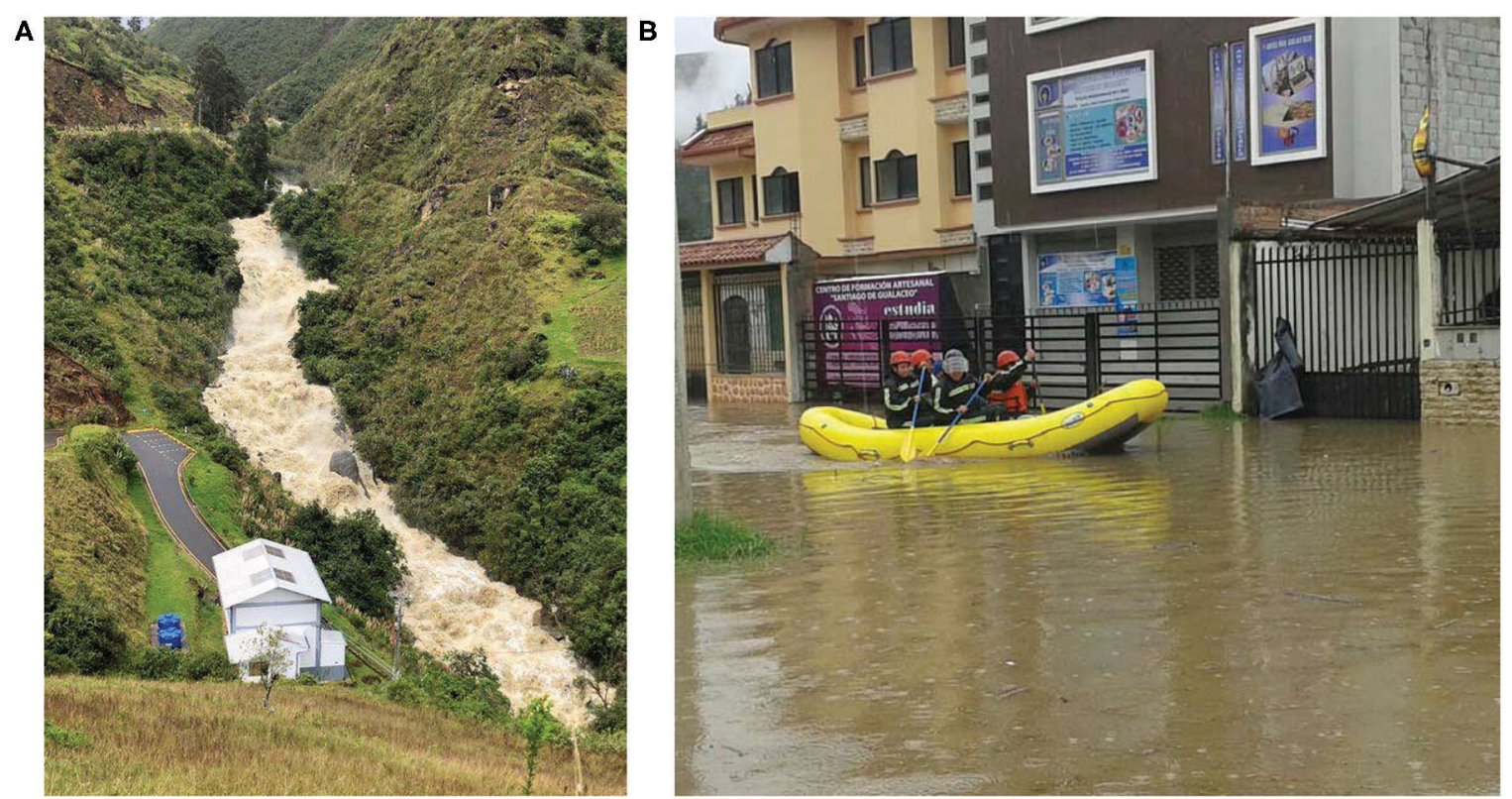

FIGURE 2 | Examples of recent riverine flooding in the Ecuadorian highlands: (A) Flood discharge of the San Francisco River (a tributary of the Santa Bárbara River) (in May 2019), (B) Gualaceo flooded by the Santa Bárbara River (in July 2017). Images courtesy of EMAPAS-G EP (left) and Municipality of Gualaceo (right).

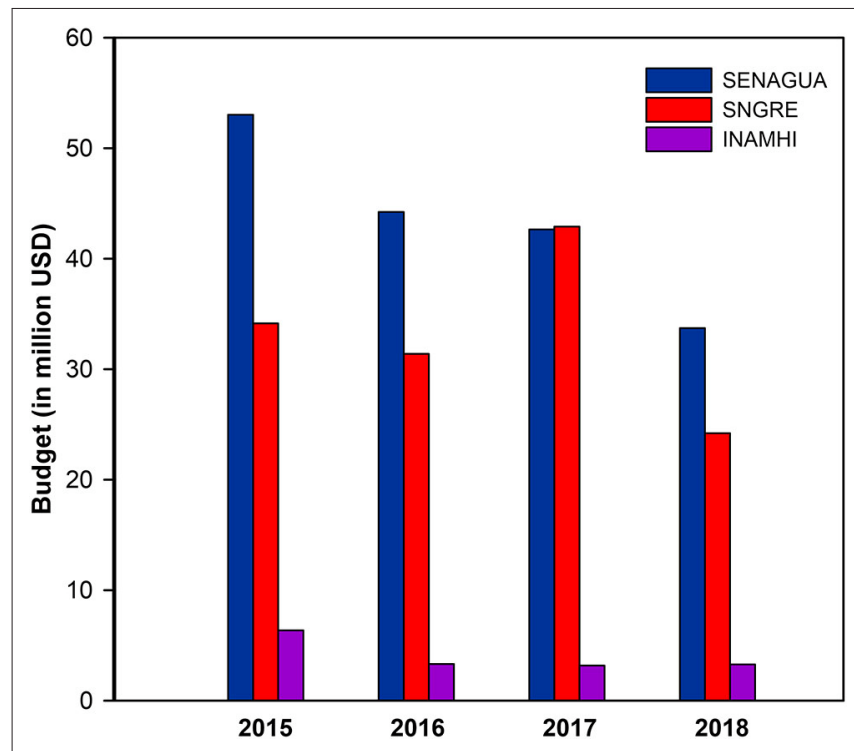

FIGURE 3 | Budgets assigned by the state to institutions related to FRM in Ecuador. Data is available through the official annual accountability reports in the corresponding sources: SENAGUA (https://www.agua.gob.ec), SNGRE (https://www.gestionderiesgos.gob.ec), and INAMHI (https://www. serviciometeorologico.gob.ec).

Fourth, an insufficient budget is allocated by the state to institutions involved in FRM (see Figure 3; annual average state budget was around 34 billion USD during the period 20152018). Moreover, the total investment in the water sector between the period 2000-2006 was 732 million USD, and for the period 2007-2016 was 1,560 million USD (SENPLADES, 2017). The investment in the water sector was lower in comparison to other Andean countries. For example, Bolivia during the period 20062016 had an investment of around 2,740 million USD (Ministerio de Medio Ambiente y Agua, 2016). Despite the investment increase of 2.13 times in Ecuador, this rise took place over a decade. However, there is no evidence that FRM has improved by the same proportion. Most of the investment was destined to multipurpose projects (irrigation systems, hydroelectric plants, flood control, etc.) instead of strengthening the environmental agencies with infrastructure, technological equipment, trained staff, etc.

Fifth, there is a lack of available historical flood records (e.g., streamflow, rainfall, flood loss records, etc.), which are the main components for flood hazard modeling and flood risk assessment (FRA). Installing and maintaining of hydrometric and meteorological monitoring stations over the mountain range is a complex task which demands continuous economic investment. Besides, low technical response capacity, limited knowledge, and/or lack of interest from environmental agencies and local governments for gathering post-flooding data are part of the problem.

Notwithstanding these and other limitations, SNGRE is developing and executing new strategies like the "National Disaster Response Plan," and SENAGUA is implementing the "National Plan for Integrated Management of Water Resources." However, their implementation at the local scale is a complex long-term task. The main long-term challenges are that any flood management strategy needs to deal with the two following aspects: 


\section{Climate Change and Climate Variability}

Dottori et al. (2018) found that for projected climate change scenarios with a $3^{\circ} \mathrm{C}$ global warmer climate, the relative increase in the population exposed to river floods could be more than triple in Ecuador when compared with the reference period (1976-2005). But as stated by Kundzewicz et al. (2019), reliable and detailed quantification of flood projections is very difficult to obtain for the past-to-present time and is virtually impossible to achieve for the future. Flood risk reduction analysis requires long-term time series of reliable records on flood-related data (Kundzewicz et al., 2019). However, Ecuador, and specifically the highlands, are poorly monitored (Celleri et al., 2007). Thus, historical data is scarce, and frequently the records are incomplete. Also, the number of hydrometeorological stations operated by INAMHI had decreased due to the historical reduction in economic resources (see Figure 3).

Regarding future flood projections, it is very difficult to obtain reliable and detailed estimations due to the multiple factors driving flood risk assessment (e.g., climatic and anthropogenic) and the considerable uncertainty associated with them (Kundzewicz et al., 2019). This is especially true for flood hazard analysis because results at a local scale are needed and the current climate models are still not accurate at this scale.

To overcome these limitations downscaling techniques have been used to obtain a finer resolution at regional scale based on the results of General Circulation Models. Moreover, a bias correction is applied to improve the estimation results using observed data (Campozano et al., 2016). In Ecuador, very few studies have evaluated the performance of downscaling methods for the Andean mountain range with a monthly resolution (Exbrayat et al., 2014; Campozano et al., 2016; Ochoa et al., 2016), mainly constrained by the lack of enough data to validate the results with ground measurements and the complex orographic features that control the rainfall patterns.

El Niño and La Niña phases of El Niño-Southern Oscillation (ENSO) together with the anomalies of the Intertropical Convergence Zone (ITCZ) greatly influence the temporal and spatial distributions of precipitation over Ecuador (Vuille et al., 2000). According to Morán-Tejeda et al. (2016), El Niño events lead to increased precipitation along the coast of Ecuador and Peru. For this region, they found a positive and strong correlation between El Niño 1+2 index and precipitation. In contrast, for the inter-Andean mountain region, there is a negative correlation of precipitation with El Niño 3.4 index. This translates into below-average precipitation for El Niño events in the mountains and above-average precipitation during La Niña events. MoránTejeda et al.'s results confirm the findings of Vuille et al. (2000), that below-average precipitation is influenced by El Niño during December-February in the northwestern Cordillera of the Andes and from June to August in the eastern Cordillera. Conversely, above-average precipitation is influenced by La Niña in the highlands. In other words, the effect of ENSO on rainfall in the Andean mountain range is the opposite of that in the coastal region (i.e., higher rainfall in the highlands and lower precipitation along the coast for La Niña events). Thus, ENSO phenomenon is another factor that adds more complexity and uncertainty to the present-day and future occurrence extreme rainfall events.

\section{Increased Population Density and Activity}

Most human settlements in the Ecuadorian highlands are found along rivers and floodplains. Despite the growing population pressure on these environments, no structural and nonstructural measures (e.g., dams, dikes, levees, zoning and development control, flood warning systems, relocation) are adopted to reduce and mitigate flood damage. Preparedness and response planning for catastrophic flooding events by the inhabitants of settlements and farms is scarce (D'Ercole and Trujillo, 2003). Currently, land-use planning along river floodplains is not based on flood hazard analysis (i.e., hydraulic modeling and flood map zoning). Generally, urban expansion control is based exclusively on a fixed distance from the river centerline (e.g., $50 \mathrm{~m})^{2}$. The increasing anthropogenic activities in the headwater basins such as deforestation and livestock production have increased surface runoff (Buytaert et al., 2006). Moreover, in-stream gravel mining for construction materials (a common practice in highlands) has resulted in active erosion with catastrophic channel widening and newly-released sediment deposition downstream that alters river geomorphology (Harden, 2006). In short, these activities amplify the risks and impacts of flooding because there is no effective cooperation and communication between agencies at the national and local levels to improve the control of these issues.

\section{WHAT TO DO?: THE NEED FOR DIVERSE STRATEGIES TO FACE FLOODS}

\section{Improved Structural Flood Control Measures}

It is well-known that mitigating the three main components of risk: hazard, exposure, and vulnerability are the best practices for FRM (Kron, 2005). Usually, structural measures are used for existing settlements, while non-structural measures are preferred for future development (Thampapillai and Musgrave, 1985). However, a combination of both measures is recommended for effective flood risk reduction, especially to tackle the residual risk (defined as the probability that a flood event may surpass all the flood management measures and cause severe losses) (Kundzewicz, 2002). Recently, several multi-objective dams were built in Ecuador (Warner et al., 2017). Both flood protection and hydroelectric power generation were the main objectives. These engineering works (e.g., Baba and Chone multi-objective projects) were focused on the coastal areas of the country, but similar projects can also be found in the highlands such as the Paute Integral Hydroelectric Complex. Nevertheless, assessment of flood scenarios induced by a potential dam-break due to a natural hazard (e.g., landslide dam collapse or dam rupture following a large earthquake) must be considered as an important issue in future FRM to support the design of integral flood control measures. The example of "La Josefina" landslide in 1993 in the

\footnotetext{
${ }^{2}$ Article No. 101-Ordinance regulating the land use and occupation in the canton of Cuenca; and Article No. 118-Quito Metropolitan Government Ordinance No. 172.
} 
Ecuadorian highlands illustrates the serious flood hazard that dams represent. About 30 million $\mathrm{m}^{3}$ of material formed an $80 \mathrm{~m}$ high blockade of the Paute River channel, creating an artificial dam of about 200 million $\mathrm{m}^{3}$. Approximately a month later, the rupture of the dam caused catastrophic flood damage in terms of infrastructure, agriculture, fatalities, and casualties $100 \mathrm{~km}$ downstream (Harden, 2001).

\section{Improved Opportunities for Relocation}

Relocation of highland people to flood-safe areas has yet to be of pivotal importance. Resettlement by government policies is not new, and it has already been applied in several developing countries as part of flood management programs (e.g., Arnall et al., 2013). However, in Ecuador, cultural, political, and economic constraints commonly block or hinder any proposal to move settlements. For example, from the cultural aspect, in some flood-prone areas such as the cities of Cuenca and Paute (province of Azuay), archaeological sites can be found with valuable information on how human behavior has changed over time [see Bray (2008)]. From the economic aspect, mountain valley topography constrains efforts to relocate settlements away from floodplains because building civil infrastructure on irregular terrains requires a significant economic investment. Finally, from the political aspect, thousands of people have established their homes in informal settlements next to the river floodplains, sometimes without legal rights to land; therefore, clearly ignoring the risk of flooding and the existing regulations on land-use along watercourses. However, local governments do not always apply sanctions to avoid public confrontations. Under these conditions, population resettlement is rare, and inhabitants choose not to move whether because of poverty, lack of education, or security reasons, among other factors. Land tenure situations add another level of complexity to the efforts of progressive FRM. Despite the exposure to flood hazards, there is no evidence of flood-prone areas becoming depopulated in the highlands. On the contrary, there are more settlements and increased farmland development.

\section{Improved Tax Revenue Schedules and Compensation}

To alleviate the costs to build new infrastructure, an adjusted tax revenue schedule could be implemented. Compensation and insurance schemes may also act as incentives or disincentives to flood-risk reduction (Suykens et al., 2016). Progressive compensation plans to motivate people to change location (i.e., reduced taxes, exemption from fees, affordable housing, etc.) could be important policy drivers to reduce flood risk. If resettlement is not feasible, people living in flood-prone areas should pay higher taxes in order to cover the post-recovery or structural protection investments that may be required postflooding.

\section{Improved Compulsory Flood Insurance}

People living in high-risk areas who are unwilling to move should be required to have flood insurance. The ability of flood insurance to contribute to direct risk reduction and recovery was extensively demonstrated (Surminski, 2014). However, flood insurance in Ecuador, which is partly covered within "fire insurance and allied policy terms," is not mandatory. Homeowners still look at these insurance products as an expense and not as protection against flood risk. The main customers of these insurance products are commercial companies due to their high asset risks.

\section{Enhanced Civil Society Participation}

Residual risk can be addressed partly by lowering the community's vulnerability to flooding. Recent works in the coastal areas of Ecuador have shown that enhancing civil society participation in open debates of FRM plans influences people's behaviors, improving their risk perception and awareness [e.g., Tauzer et al. (2019)]. These factors are key to the development of people's resilience (defined as the process of adapting well and the capacity to reorganize while undergoing change and recover quickly) to floods. Detailed data about people's perceptions of their risk is a key factor to improve risk communication to the public (Botzen et al., 2009). In addition, when designing the risk message, three factors should be considered (i) the format of the message, (ii) a trusted source issuing the message, and (iii) the risk target (Williams and Noyes, 2007). The proper application of this process will help influence people's perceptions to take part in risk reduction actions implemented by the government.

\section{Citizen Involvement in Decision-Making}

Modern flood risk governance should include citizens in decision-making. In this way, the implementation of specific measures would be more acceptable by the general society [e.g., Haque et al. (2002)]. This also will promote communitybased initiatives and organizations for the sake of seeking better resilience (Tauzer et al., 2019). To effectively contribute to decision-making, citizens benefit from participating in training programs, such as flood drill campaigns, and educational interventions, which rarely occurs. In general, these types of exercises were unsuccessfully carried out in the highlands (e.g., Gualaceo and the surrounding areas).

\section{Improved Flood Warning Systems}

Well-developed flood warning systems and flood emergency management operations are essential to achieve appropriate FRM. Such measures alert people of an imminent threat and assist them to protect life and minimize flood damage. The use of social media and traditional sirens or loudspeakers is an effective way to alert people for evacuations. Just a small number of mountain cities, such as Cuenca and Cañar, have implemented an operative real-time early warning system (Paez-Bimos, 2014). The absence of such systems in most highland settlements and communities is common, or if they exist, they are inadequate or non-operative. Moreover, INAMHI has only six hydrometric stations that are fully operative in the inter-Andean region with real-time transmission using the Geostationary Operational Environmental Satellite (GOES) system. This network uses a basic warning system based on a color code (green: normal water level, yellow: increasing water level, and red: dangerous water level). This alarming reality leaves vulnerable inhabitants exposed to financial losses, increasing poverty, and human casualties. 


\section{Smart Land-Use Planning}

Smart land-use planning is a fundamental tool to prevent flood exposure by minimizing development in flood-prone zones. These planning measures include the reduction of water runoff through catchment management along with designating routes and open spaces for better response and recovery efforts and the regulation and management of in-stream gravel mining. In addition, remote sensing and geographic information systems (GIS) are widely used on the acquisition of detailed and accurate land-use information for the management and planning of urban regions. These measures and techniques would be effective in mitigating damage from unavoidable floods and enhance the development of urban growth and expansion in flood-safe areas.

\section{Cross-Institutional Collaboration}

An evaluation of the different roles of governmental institutions related to FRM is required for a deep understanding of the competences of each institution. This evaluation will allow the development of methodologies to integrate these institutions in a more effective way (i.e., effective cooperation and communication) and to identify in which areas/departments specialized staff and equipment are required. Such crossinstitutional collaboration helps to overcome barriers such as the limited technical and response capacity. It is especially important to engage individual faculty, departments and institutes at Ecuadorian universities in this review of institutional competencies and in the development of collaborative strategies. This integration will support comprehensive and multidisciplinary research on flood-related topics, which is a key strategy for effective management based on scientific and technical foundations.

\section{Improved Data Collection}

INAMHI hast two types of monitoring systems, meteorological (mainly rainfall) and hydrological (water levels/discharges). However, the network density is insufficient to characterize the high variability of rainfall in space and time, especially in the highlands. Even the Paute River basin, with one of the densest rainfall networks in the Ecuadorian Andes, has an average density of one rainfall station per $360 \mathrm{~km}^{2}$ in areas above 3,000 masl. This density is below the minimum recommended by the World Meteorological Organization for mountain areas (one station per $250 \mathrm{~km}^{2}$ ) (Celleri et al., 2007).Thus, there is a huge gap in reliable information on past flood events, which is a big challenge that needs to be filled to understand different inundation dynamics, trends, and hydrology relationships. Systematic monitoring of flood events is necessary for the validation of flood risk and hazard models that will help in the decision-making process. Since a high spatial and temporal variability of rainfall is expected within the Andean mountain range, efficient distribution of new types of hydrometeorological networks is required [e.g., Contreras et al. (2019)] to reduce investment and maintenance costs, but without compromising modeling accuracy (Sucozhañay and Célleri, 2018). In recent years, citizen science has shown an increasing potential for hydrological data collection in remotes areas such as mountains by applying simple downloading procedures from
TABLE 1 | Research agenda for floods and their mitigation in Ecuadorian highlands.

\section{(Bio)Geomorphology}

What are the mechanisms and impacts of the debris flow, and sediment transport along with its deposition?

Is there a correlation between floods and mountain river morphology?

What is the role of vegetation in flood episodes? Would increasing forest cover reduce flood risks in mountain catchments?

\section{Models and Modeling}

How can hydrodynamic models be adapted to assess the specific hydraulic conditions of mountain rivers (e.g., steep slopes and abrupt cross-section changes)?

Would the development and application of flood loss models improve decision-making by governmental agencies in the Ecuadorian context?

What are the costs and benefits of different flood protection scenarios (e.g., structural and non-structural measures)?

How can we quantify and reduce the uncertainty propagation in the flood risk assessment chain?

Will climate change increase or reduce potential flood damage in the inter-Andean region?

To what extent does ENSO influence the frequency of floods along the Ecuadorian highlands?

\section{Planning}

What are the potential downstream flood impacts generated by dam breaks and what are the possible emergency countermeasures for possible catastrophic collapse of the mountain dams?

What are the advantages of assessing the spatial-temporal dynamics of the floods in highlands using open-access remote sensing for planning and development?

\section{Social}

What is needed to evaluate the physical exposure and socio-economic vulnerability (e.g., flood-risk perception) of highlands inhabitants?

What are the factors that control the population's self-decision to stay in flood-prone areas?

What is required to assess, improve, and innovate flood recovery plans (e.g., "build back better" practices)?

How can institutions work together to develop a standard methodological framework for warning and emergency response systems at regional or national level?

Is flood risk an issue of technological shortage or an issue of social resilience and civic self-care in the Andean communities of Ecuador?

automated low-maintenance sensors (Buytaert et al., 2014). This approach allows the establishment of denser networks and will increase the accuracy of flooding predictions. However, citizen science is still incipient in our country. According to Njue et al. (2019), only nine sites have been identified in the Andes of Peru, Ecuador, and Bolivia where citizen science in hydrologic monitoring (precipitation and streamflow) is applied, led by the Program "Initiative for Hydrological Monitoring of Andean Ecosystems."

\section{Improved Flood Modeling Vulnerability Assessment}

Very few research studies have tested the performance of onedimensional (e.g., HECRAS, MIKE 11, Flood Modeler) and twodimensional (e.g., HEC-RAS 2D, Iber 2D, Flood Modeler 2D, 
PCSWMM 2D) flood models for mountain rivers in Ecuador (Pinos and Timbe, 2019; Pinos et al., 2019). This is in spite of an increased interest in hydrodynamic flood modeling and flood forecasting [e.g., Muñoz et al. (2018), Ochoa-Sánchez et al. (2018)] and greater recognition of vulnerability of the Andean locations to flooding [e.g., Jerez (2017), Hinojosa (2018)]. In general, public domain software is more popular for hydrologic and hydraulic modeling (e.g., HEC-HMS, HBV-light, HEC-RAS, Iber 2D), particularly at research institutions. However, there are no protocols for the selection and use of hydrologic and hydraulic models, floodway analysis and development, flood mapping and zoning; among the most important. Thus, the development of general national standards and guidelines in the field of FRM is sorely needed.

\section{CONCLUDING REMARKS: AN AGENDA FOR FUTURE ACTIONS AND RESEARCH}

There are many knowledge gaps that need to be filled to better understand crucial issues and elements of mountain riverine floods in Ecuador. These knowledge gaps should be the focus of active areas of research for flood risk management. Sixteen

\section{REFERENCES}

Arnall, A., Thomas, D. S., Twyman, C., and Liverman, D. (2013). Flooding, resettlement, and change in livelihoods: evidence from rural Mozambique. Disasters 37, 468-488. doi: 10.1111/disa.12003

Botzen, W. J. W., Aerts, J. C. J. H., and Van Den Bergh, J. C. J. M. (2009). Dependence of flood risk perceptions on socioeconomic and objective risk factors. Water Resour. Res. 45:W10440. doi: 10.1029/2009WR007743

Bray, T. L. (2008). "Late pre-hispanic chiefdoms of highland Ecuador," in The Handbook Of South American Archaeology, eds H. Silverman, and W. H. Isbell. (New York, NY: Springer), 527-543. doi: 10.1007/978-0-387-74907-5_27

Bubeck, P., Kreibich, H., Penning-Rowsell, E., Botzen, W., de Moel, H., and Klijn, F. (2017). Differences in flood management approaches. J. Flood Risk Manag. 10, 436-445. doi: 10.1111/jfr3.12151

Buytaert, W., Célleri, R., De Bièvre, B., Cisneros, F., Wyseure, G., Deckers, J., et al. (2006). Human impact on the hydrology of the Andean paramos. Earth-Sci. Rev. 79, 53-72. doi: 10.1016/j.earscirev.2006.06.002

Buytaert, W., Zulkafli, Z., Grainger, S., Acosta, L., Alemie, T. C., Bastiaensen, J., et al. (2014). Citizen science in hydrology and water resources: opportunities for knowledge generation, ecosystem service management, and sustainable development. Front. Earth Sci. 2:26. doi: 10.3389/feart.2014.00026

Campozano, L., Tenelanda, D., Sanchez, E., Samaniego, E., and Feyen, J. (2016). Comparison of statistical downscaling methods for monthly total precipitation: case study for the Paute river basin in Southern Ecuador. Adv. Meteorol. 2016:6526341. doi: 10.1155/2016/6526341

Celleri, R., Willems, P., Buytaert, W., and Feyen, J. (2007). Space-time rainfall variability in the Paute basin, Ecuadorian Andes. Hydrol. Process. 21, 3316-3327. doi: 10.1002/hyp.6575

Contreras, J., Ballari, D., Bruin, S., and Samaniego, E. (2019). Rainfall monitoring network design using conditioned Latin hypercube sampling and satellite precipitation estimates: an application in the ungauged Ecuadorian Amazon. Int. J. Climatol. 39, 2209-2226. doi: 10.1002/joc.5946

D'Ercole, R., and Trujillo, M. (2003). Amenazas, Vulnerabilidad, Capacidades y Riesgo en el Ecuador. Quito: Los Desastres; un Reto Para el Desarrollo; COOPI; OXFAM-GB, 225.

Dottori, F., Szewczyk, W., Ciscar, J. C., Zhao, F., Alfieri, L., Hirabayashi, Y., et al. (2018). Increased human and economic losses from river key issues in the form of questions have been identified based on strategies discussed in the previous section, that should be considered to improve FRM in the highlands of Ecuador. This research agenda for flood mitigation is presented in Table 1. Answers to these key questions will greatly improve flood hazard identification and flood risk management at the Andean mountain range of Ecuador.

\section{DATA AVAILABILITY STATEMENT}

The original contributions presented in the study are included in the article/supplementary material, further inquiries can be directed to the corresponding author/s.

\section{AUTHOR CONTRIBUTIONS}

All authors listed have made a substantial, direct and intellectual contribution to the work, and approved it for publication.

\section{ACKNOWLEDGMENTS}

The authors would like to thank the reviewers for their insightful suggestions and careful reading of the manuscript. flooding with anthropogenic warming. Nat. Clim. Change. 8, 781-786. doi: 10.1038/s41558-018-0257-z

Exbrayat, J., Buytaert, W., Timbe, E., Windhorst, D., and Breuer, L. (2014). Addressing sources of uncertainty in runoff projections for a data scarce catchment in the Ecuadorian Andes. Clim. Change. 125, 221-235. doi: 10.1007/s10584-014-1160-x

Galarza-Villamar, J. A., Leeuwis, C., Pila-Quinga, G. M., Cecchi, F., and PárragaLema, C. M. (2018). Local understanding of disaster risk and livelihood resilience: the case of rice smallholders and floods in Ecuador. Int. J. Disast. Risk Re. 31, 1107-1120. doi: 10.1016/j.ijdrr.2018.08.009

Haque, C. E., Kolba, M., Morton, P., and Quinn, N. P. (2002). Public involvement in the Red River Basin management decisions and preparedness for the next flood. Global Environ. Change B Environ. Hazards. 4, 87-104. doi: 10.3763/ehaz.2002.0411

Harden, C. (2001). Sediment movement and catastrophic events: the 1993 rockslide at La Josefina, Ecuador. Phys. Geogr. 22, 305-320. doi: 10.1080/02723646.2001.10642745

Harden, C. (2006). Human impacts on headwater fluvial systems in the northern and central Andes. Geomorphology 79, 249-263. doi: 10.1016/j.geomorph.2006.06.021

Hinojosa, E. A. (2018). Análisis de percepción de riesgos de la población de la parroquia Centro Histórico de Quito frente a posibles amenazas naturales. (Bachelor's thesis). Pontificia Universidad Católica del Ecuador, Quito, Ecuador.

Jerez, M. A. (2017). Valoración de la vulnerabilidad física estructural para viviendas ante inundaciones en la parte céntrica del cantón San Pedro de Pelileo. (Bachelor's thesis). Universidad Técnica de Ambato, Ambato, Ecuador.

Knight, D. W. (2013). River hydraulics - a view from midstream. J. Hydraul. Res. 51, 2-18. doi: 10.1080/00221686.2012.749431

Kron, W. (2005). Flood risk = hazard $\bullet$ values $\bullet$ vulnerability. Water Int. 30, 58-68. doi: 10.1080/02508060508691837

Kundzewicz, Z. W. (2002). Non-structural flood protection and sustainability. Water Int. 27, 3-13. doi: 10.1080/02508060208686972

Kundzewicz, Z. W., Su, B., Wang, Y., Wang, G., Wang, G., Huang, J., et al. (2019). Flood risk in a range of spatial perspectives-from global to local scales. Nat. Hazards Earth Syst. Sci. 19, 1319-1328. doi: 10.5194/nhess-19-131 9-2019 
Ministerio de Medio Ambiente y Agua (2016). Rendición Pública de Cuentas 2016. (La Paz, Bolivia).

Morán-Tejeda, E., Bazo, J., López-Moreno, J. I., Aguilar, E., Azorín-Molina, C., Sanchez-Lorenzo, A., et al. (2016). Climate trends and variability in Ecuador (1966-2011). Int. J. Climatol. 36, 3839-3855. doi: 10.1002/joc.4597

Muñoz, P., Orellana-Alvear, J., Willems, P., and Célleri, R. (2018). Flash-flood forecasting in an andean mountain catchment - development of a stepwise methodology based on the random forest algorithm. Water 10:1519. doi: 10.3390/w10111519

Njue, N., Stenfert Kroese, J., Gräf, J., Jacobs, S. R., Weeser, B., Breuer, L., et al. (2019). Citizen science in hydrological monitoring and ecosystem services management: state of the art and future prospects. Sci. Total Environ. 693:133531. doi: 10.1016/j.scitotenv.2019.07.337

Ochoa, A., Campozano, L., Sánchez, E., Gualán, R., and Samaniego, E. (2016). Evaluation of downscaled estimates of monthly temperature and precipitation for a Southern Ecuador case study. Int. J. Climatol. 36, 1244-1255. doi: $10.1002 /$ joc. 4418

Ochoa-Sánchez, A., Timbe, L., Vázquez-Patiño, A., and Samaniego, E. (2018). Unidimensional, non-stationary modeling of a high mountain river in southern Ecuador. Maskana 9, 67-74. doi: 10.18537/mskn.09.02.08

Paez-Bimos, S. (2014). "Hidrometeorología en el Azuay y Sistemas de Alerta Temprana Hidrometeorológicos ante inundaciones por crecidas de ríos (SAT)" in Re-flexiones Académicas en el marco del Proyecto "Fortalecimiento del Sistema Nacional descentralizado de Gestión de Riesgos". ed M. E. Estrella (Quito: PYDLOS - Universidad de Cuenca), 50-60.

Pinos, J., and Timbe, L. (2019). Performance assessment of two-dimensional hydraulic models for generation of flood inundation maps in mountain river basins. Water Sci. Eng. 12, 11-18. doi: 10.1016/j.wse.2019.03.001

Pinos, J., Timbe, L., and Timbe, E. (2019). Evaluation of 1D hydraulic models for the simulation of mountain fluvial floods: a case study of the Santa Bárbara River in Ecuador. Water Pract. Technol. 14, 341-354. doi: 10.2166/wpt.2019.018

Sarmiento, F. O., and Frolich, L. M. (2002). Andean cloud forest tree lines. Mt. Res. Dev. 22, 278-287. doi: 10.1659/0276-4741(2002)022[0278:ACFTL]2.0.CO;2

SENAGUA (2011). Evaluación de Vulnerabilidad a Eventos de Inundación del río Yanuncay, Vol 2, Estudio Hidráulico. (Quito: SENAGUA), 203.

SENAGUA (2014). Evaluación de Vulnerabilidad a Eventos de Inundación del río Santa Bárbara, Vol 2, Estudio Hidráulico. (Quito: SENAGUA), 108.

SENPLADES (2012). Costos de las Pérdidas por las Inundaciones. Boletín Informativo I. Ecuador.
SENPLADES (2017). Informe a la Nación 2007-2017. Quito.

Sucozhañay, A., and Célleri, R. (2018). Impact of rain gauges distribution on the runoff simulation of a small mountain catchment in southern ecuador. Water 10:1169. doi: $10.3390 /$ w10091169

Surminski, S. (2014). The role of insurance in reducing direct risk: the case of flood insurance. IRERE 7, 241-278. doi: 10.1561/101.00000062

Suykens, C., Priest, S. J., van Doorn-Hoekveld, W. J., Thuillier, T., and Van Rijswick, M. (2016). Dealing with flood damages: will prevention, mitigation, and ex post compensation provide for a resilient triangle? Ecol. Soc. 21:4. doi: 10.5751/ES-08592-210401

Tauzer, E., Borbor-Cordova, M. J., Mendoza, J., De La Cuadra, T., Cunalata, J., and Stewart-Ibarra, A. M. (2019). A participatory community case study of periurban coastal flood vulnerability in southern Ecuador. PLoS ONE 14:10. doi: 10.1371/journal.pone.0224171

Thampapillai, D. J., and Musgrave, W. F. (1985). Flood damage mitigation: a review of structural and nonstructural measures and alternative decision frameworks. Water Resour. Res. 21, 411-424. doi: 10.1029/WR021i004p 00411

Vuille, M., Bradley, R. S., and Keimig, F. (2000). Climate variability in the Andes of Ecuador and its relation to tropical Pacific and Atlantic sea surface temperature anomalies. J. Climate. 13, 2520-2535. doi: 10.1175/1520-0442(2000)013\&lt;2520:CVITAO\&gt;2.0.CO;2

Warner, J. F., van Dijk, J. H., and Hidalgo, J. P. (2017). Old wine in new bottles: the adaptive capacity of the hydraulic mission in Ecuador. Water Altern. $10,332-340$.

Williams, D. J., and Noyes, J. M. (2007). How does our perception of risk influence decision-making? implications for the design of risk information. Theor. Issues Ergon. Sci. 8, 1-35. doi: 10.1080/14639220500484419

Conflict of Interest: The authors declare that the research was conducted in the absence of any commercial or financial relationships that could be construed as a potential conflict of interest.

Copyright (c) 2020 Pinos and Timbe. This is an open-access article distributed under the terms of the Creative Commons Attribution License (CC BY). The use, distribution or reproduction in other forums is permitted, provided the original author(s) and the copyright owner(s) are credited and that the original publication in this journal is cited, in accordance with accepted academic practice. No use, distribution or reproduction is permitted which does not comply with these terms. 